\title{
Integrated Approach for the Management of Soil Borne Disease Fusarium oxysporum in vitro in Groundnut
}

\author{
S. Vasumathi and P. Ahila Devi* \\ Kalasingam University, Krishnankovil, Virudhunagar District -626001, India \\ National Pulses Research Centre, Vamban, Pudukottai District, India \\ *Corresponding author
}

\begin{tabular}{|l|}
\hline \multicolumn{1}{|l}{} \\
\hline Ke y w or d s \\
Oilcake extract, \\
Crude antibiotic, \\
pathogen
\end{tabular}

A B S T R A C T

All the three bicontrol agents were found to be compatible with each other. Among the various oilcake extracts tested, mahua cake (10\%) inhibited the mycelial growth of $F$. oxysporum to an extent of 60.77 per cent. The crude antibiotic extracted from $\mathrm{Pf}_{1}$ showed maximum growth inhibition of $F$. oxysporum up to 63.33 per cent. The diffusible non-volatile metabolite of $\mathrm{Tv}_{1}$ was effective in retarding the growth of the pathogen up to 91.44 per cent. The volatiles released by $\mathrm{Tv}_{1}$ reduced the growth of the pathogen by 87.55 per cent. Production of HCN was observed to be in higher quantity in $\mathrm{Pf}_{1}$ and $\mathrm{Pf}_{2}$ while isolates of $B$. subtilis did not produce the same. Two isolates of $P$. fluorescens $\left(\mathrm{Pf}_{1}, \mathrm{Pf}_{2}\right)$ and $T$. viride $\left(\mathrm{TV}_{1}\right.$ and $\left.\mathrm{TV}_{2}\right)$ produced siderophore whereas the isolates of $B$. subtilis $\left(\mathrm{Bs}_{2}, \mathrm{Bs}_{10}\right)$ were negative for the same. $\mathrm{Pf}_{1}$ and $\mathrm{Pf}_{2}$ produced more $\mathrm{SA}$ than $\mathrm{Bs}_{2}$ and $\mathrm{Bs}_{10}$

\section{Introduction}

Groundnut plants affected with wilt exhibited greyish green discolouration and flaccidity of leaves followed by yellowing of foliage and wilting. Vascular browning of internal tissues was also noticed. In the pathogenicity tests carried out in vitro as well as in vivo, plants inoculated F.oxysporum produced the same symptoms as observed in the field. The findings corroborate with that of Jofee (1973) who observed bleaching of foliage, drying of canopy with vascular browning of tap roots in wilt of groundnut caused by F.oxysporum. In cotton infection caused by $F$. oxysporum f.sp. vasinfectum lead to loss of leaf turgidity, leaf yellowing and withering. Wilting was either partial or complete.

Tap roots were stunted with browning and blackening of vascular tissues (Prakasam et al., 1993). In gingelly symptoms of Fusarium wilt include partial or total wilting of plants at flowering and podding, with a purple band 
extending from the base upwards. When the main stem or primary branches were split browning or blackening of internal tissue was noticed (Correll, 2005).

\section{Materials and Methods}

\section{Preparation of aqueous extracts from oil} cakes

Required quantity of each oil cake was weighed and powdered separately. The powder was soaked in sterile distilled water @ oneg in $1.25 \mathrm{ml}$ of water and kept overnight. The material was ground using a pestle and mortar filtered, through a muslin cloth and the filtrate was centrifuged at $10,000 \mathrm{rpm}$ for $15 \mathrm{~min}$. The supernatant served as the standard extract solution (100\%) (Dubey and Patel, 2000).

Testing the antifungal activity of oil cake extracts against $F$.oxysporum in vitro

The efficacy of oil cake extracts was tested against F.oxysporum by poisoned food technique (Schmitz, 1930). Ten $\mathrm{ml}$ of aqueous extract of oil cake was mixed with $90 \mathrm{ml}$ of PDA to obtain 10 per cent concentration and sterilized. The sterilized medium $(15 \mathrm{ml}$ per Petri dish) was poured in sterilize Petri dish and allowed to solidify. A five- mm mycelial disc of F.oxysporum was cut from actively growing culture and placed at the centre of each Petri dish and incubated at room temperature. PDA medium without the extract of oil cake served as control. The radial growth of F.oxysporum was recorded 7 DAI.

\section{Screening of fungicides in vitro}

The inhibitory effect of six fungicides viz., carbendazim, Kocide $1011 \quad$ (35\% metallic copper), copper oxychloride, benomyl, Saff (carbendazim + mancozeb) and Curzate (cymoxanil + mancozeb) each at four concentrations $(0.05 \%, 0.1 \%, 0.15 \%, 0.2 \%)$ on the growth of $F$. oxysporum were evaluated by poisoned food technique (Schmitz, 1930). Each treatment was replicated three times with proper control. The fungal growth was measured after seven days and per cent inhibition was calculated.

\section{Biochemical characterization of $P$. fluorescens and B. subtilis}

The effective bacterial antagonists screened against $F$. oxysporum were identified and characterized based on the diagnostic tests detailed in the laboratory guide of Schaad (1992).

Diagnostic tests for $\boldsymbol{P}$. fluorescens (Table 3)

\section{Gram staining}

Gram staining was carried out to differentiate the bacteria as Gram-positive or negative.

\section{KOH test}

A drop of bacterial suspension was thoroughly mixed with a drop of $3 \% \mathrm{KOH}$ on a glass slide. Gram negative bacteria became gummy upon mixing due to separation of chromosomes as thin strands.

\section{Growth at $45^{\circ} \mathrm{C}$ and $4^{\circ} \mathrm{C}$}

Bacterial cultures were inoculated in $\mathrm{KB}$ broth and incubated at $45^{\circ} \mathrm{C}$ and $4{ }^{\circ} \mathrm{C}$ and those with turbidity after 24 to $48 \mathrm{~h}$ were recorded as positive.

\section{Fluorescent pigment production}

Cultures were streaked on $\mathrm{KB}$ medium and incubated at room temperature. After $48 \mathrm{~h}$ the colonies were examined for fluorescence under ultraviolet rays. 


\section{Leaven formation}

The 24-h-old cultures were streaked on NA medium with $5 \%$ sucrose $(\mathrm{w} / \mathrm{v})$ and incubated at room temperature.

The presence or absence of convex, white mucoid colonies was observed after 3-5 days.

\section{Arginine dihydrolase reaction}

Cultures were stabbed into a tube of Fhornley's medium and over laid with sterile mineral oil. The tubes were incubated at $28 \pm$ $2^{\circ} \mathrm{C}$. The faint pink colour of the medium turning to red (alkaline) in four days indicated positive reaction.

\section{Gelatin liquefaction}

Cultures were streaked on NA with $0.4 \%$ gelatin in a Petri plate and incubated at $28 \pm$ $2^{\circ} \mathrm{C}$ for three days. The surface of the medium was flooded with $10 \mathrm{ml}$ of acidified mercuric chloride solution $\left(\mathrm{HgCl}_{2}-12 \mathrm{~g}\right.$, distilled water - $80 \mathrm{ml}$, conc. $\mathrm{HCl}-16 \mathrm{ml}$ ).

Clear zone around the colonies indicated a positive reaction.

\section{Diagnostic tests for $B$. subtilis (Table 4)}

\section{Utilization of citrate}

The slants with Simmons citrate agar were streaked with cultures and incubated at room temperature $\left(28 \pm 2^{\circ} \mathrm{C}\right)$. When the inoculated green colour of the medium turned blue after $24-48 \mathrm{~h}$, it indicated the utilization of citrate by the bacteria.

\section{Growth in $7 \%$ NaCl}

Cultures were inoculated in nutrient broth with 0.5 glucose and $7 \% \mathrm{NaCl}$ and the growth was observed daily up to seven days.

\section{Anaerobic growth in glucose broth}

Glucose broth was inoculated with test cultures, over laid with sterile mineral oil and incubated at $28 \pm 2{ }^{\circ} \mathrm{C}$. The growth of the cultures was observed after $48 \mathrm{~h}$ of incubation.

\section{Starch hydrolysis}

Petri dishes containing starch agar were streaked with test cultures. After five days of incubation, the plates were flooded with Lugol's iodine. Clear, colourless zone around the colonies indicated positive reaction for starch hydrolysis.

\section{Catalase test}

Bacterial cultures were inoculated on to NA slants. After $24 \mathrm{~h}$, one $\mathrm{ml}$ of $3 \% \mathrm{H}_{2} \mathrm{O}_{2}$ was allowed to flow over the surface of the culture and the production of bubbles of gas indicated positive reaction.

\section{Mode of action of biocontrol agents}

\section{Antibiotic production - bacterial antagonists}

\section{Extraction of crude antibiotic metabolites}

The bacterial biocontrol agents viz., $\mathrm{Bs}_{1}, \mathrm{Bs}_{10}$, $\mathrm{Pf}_{1}$ and $\mathrm{Pf}_{2}$ grown for five days in pigment production broth were centrifuged at 5000 rpm for $30 \mathrm{~min}$. The supernatant was adjusted to $\mathrm{pH} 2.0$ with concentrated $\mathrm{HCl}$ and extracted with equal volume of benzene. The benzene layer was evaporated in a water bath and the residue was resuspended in $0.1 \mathrm{~N}$ $\mathrm{NaOH}$ (Rossales et al., 1995).

\section{Effect of bacterial antibiotics on the growth} of $F$. oxysporum

The effect of antibiotics extracted from bacterial antagonists was tested against the 
growth of F.oxysporum by filter paper disc assay (Lam and $\mathrm{Ng}$, 2001). Three sterile filter paper discs were placed on solidified PDA in Petri dishes. The crude antibiotic extracted was pipetted on filter paper @ $150 \mu \mathrm{l} /$ disc. A five-mm- mycelial disc of the fungus was placed at the centre of the plate and incubated at $28 \pm 2{ }^{\circ} \mathrm{C}$. Filter paper without antibiotic served as control. Surface area of inhibition was measured by tracing the area of inhibition in a trace paper, plotting it on a graph sheet and comparing with control.

Effect of non-volatile metabolites of T.viride on the growth of the F.oxysporum

The effect of non-volatile, diffusible metabolites of T.viride on the growth of F.oxysporum was studied by the method of Dennis and Webster (1971). Sterilized cellophane disc of 90-mm-dia was layered on top of the PDA in Petri plates. Five- mm-disc of Trichoderma spp. was placed at the centre of the cellophane disc and plates were incubated at $28^{\circ} \mathrm{C}$ for three days. The cellophane disc along with the growth of Trichoderma was gently and aseptically removed on $3^{\text {rd }}$ day and five-mm-disc of pathogen from actively growing culture was placed at the centre of PDA and the plates were incubated again. The diameter of the fungal growth was measured when the control plate attained the full growth.

\section{Effect of volatiles of biocontrol agents on the growth of F.oxysporum}

The inhibitory effect of volatiles produced by biocontrol agents on the growth F.oxysporum was estimated by paired Petri-plate technique (Laha et al., 1996). The isolates of $P$. fluorescens and B. subtilis were streaked on $\mathrm{KB}$ and NA respectively. For T.viridea five mm-mycelial disc of the fungus was placed at the centre of PDA plate. The plates with PDA inoculated with pathogen at the centre were inverted over the plates having the antagonists and both the plates were sealed together with Parafilm and incubated at $28 \pm 2{ }^{\circ} \mathrm{C}$. PDA plates with the pathogen inverted over the plates without antagonist served as control. The inhibitory effect of volatiles produced by biocontrol agents was assessed based on the mycelial growth of the pathogen when compared to control.

\section{Hydrogen cyanide (HCN) production}

\section{Qualitative assay}

HCN production of fungal and bacterial biocontrol agents was tested qualitatively following the method of Bakker and Schipper (1987). The antagonistic bacteria were streaked on KB medium amended with glycine at $4.4 \mathrm{~g} / 1$. In case of Trichoderma, a five- $\mathrm{mm}$ mycelial disc of the fungus was placed at the cenre of plate containing PDA amended with glycine.

Sterile filter paper saturated with picric acid solution (2.5 g of picric acid; $12.5 \mathrm{~g}$ of $\mathrm{Na}_{2} \mathrm{CO}_{3}, 1000 \mathrm{ml}$ of distilled water) was placed in the upper lid of the Petri plate. The dishes were sealed with Parafilm and incubated at $28^{\circ} \mathrm{C}$ for $48 \mathrm{~h}$. A change of colour of the filter paper from yellow to light brown, brown or reddish-brown was recorded as weak $(+)$, moderate $(++)$ or strong $(+++)$ reaction respectively.

\section{Quantitative assay}

Antagonistic bacteria were grown in $\mathrm{KB}$ broth amended with glycine $(4.4 \mathrm{~g} / 1)$ while T.viridewas cultured on potato dextrose broth containing glycine. Uniform strips of filter paper $\left(10 \times 0.5 \mathrm{~cm}^{2}\right)$ were soaked in alkaline picrate solution and kept hanging inside the conical flask. After incubation at $28 \pm 2{ }^{\circ} \mathrm{C}$ for $48 \mathrm{~h}$ the sodium picrate in the filter paper was reduced to a reddish compound in proportion 
to the amount of $\mathrm{HCN}$ evolved. The colour was eluted by placing the filter paper in a test tube containing $10 \mathrm{ml}$ of distilled water and its absorbance was read at $625 \mathrm{~nm}$ (Sadasivam and Manickam, 1992).

\section{Siderophore production}

\section{Qualitative assay}

Forty eight-h-old bacterial cultures were streaked on succinate medium amended with indicator dye. In case of Trichoderma, a five mm-mycelial disc of the fungus was placed at the centre of the plate containing the same medium. The tertiary complex chrome azural $\mathrm{S}$ (CAS) / $\mathrm{Fe}^{3+} /$ hexadecyl trimethyl ammonium bromide served as an indicator.

Change of blue colour of the medium surrounding the growth of the culture to fluorescent yellow indicated the production of siderophore. The reaction of each bacterial strain was scored either positive or negative to the assay (Schwyn and Neilands, 1987).

\section{Nature of siderophore}

The bacterial isolates of $P$. fluorescens and $B$. subtilis were inoculated in $10 \mathrm{ml}$ of $\mathrm{KB}$ broth and nutrient broth respectively. The cultures were incubated in a rotary shaker at $120 \mathrm{rpm}$ for $48 \mathrm{~h}$. The bacteria multiplied in the broths were used as the sample for the determination of the nature of siderophore.

\section{Hydroxymate type}

It was examined by tetrazolium salt test. Instant appearance of a deep red colour by addition of tetrazolium salt to the culture under alkaline conditions indicated the presence of hydroxymate type of siderophore production (Snow, 1984).

\section{Carboxylate type}

The assay was conducted by Vogeli's chemical test where the disappearance of pink colour on addition of phenolphthalein to the culture under alkaline condition indicated carboxylate nature of siderophore (Vogeli et al., 1998).

\section{Quantitative assay}

P. fluorescens and B. subtilis were grown on $\mathrm{KB}$ and nutrient broth respectively. After three days, the cultures were centrifuged at $10,000 \mathrm{rpm}$ for 20 minutes. The $\mathrm{pH}$ of the cell free culture filtrate was adjusted to 2.0 with $\mathrm{HCl}$ and equal quantity of ethyl acetate was added, mixed well in a separating funnel and the ethyl acetate fraction was collected. The process was repeated three times to bring the entire quantity of siderophore from the supernatant.

The ethyl acetate fractions were pooled, air dried and dissolved in five $\mathrm{ml}$ of $50 \%$ ethanol. Five $\mathrm{ml}$ of the fraction was mixed with five $\mathrm{ml}$ of Hathway reagent $\left(1.0 \mathrm{ml}\right.$ of $0.1 \mathrm{M} \mathrm{FeCl}_{3}$ in $0.1 \mathrm{~N} \mathrm{HCl}$ to $100 \mathrm{ml}$ of distilled water with $1.0 \mathrm{ml}$ of potassium ferricyanide). The absorbance of dihydroxy phenol was measured at $700 \mathrm{~nm}$ (Reeves et al., 1983). The quantity of siderophore produced was calculated using a standard graph of dihydroxy benzoic acid (Dileep et al., 1998) and expressed as $\mu \mathrm{g} \mathrm{ml}^{-1}$ of culture filtrate.

\section{Salicylicacid (SA) production}

The antagonistic bacteria were grown in succinate broth for $48 \mathrm{~h}$ at $28 \pm 2{ }^{\circ} \mathrm{C}$. Cultures were centrifuged at $10,000 \mathrm{rpm}$ for $20 \mathrm{~min}$. and the supernatant was used to quantify the $\mathrm{SA}$ production. Four $\mathrm{ml}$ of the supernatant was acidified with $1 \mathrm{~N} \mathrm{HCl}$ to $\mathrm{pH} 2.0$ and extracted with equal volume of chloroform. 
Four $\mathrm{ml}$ of water and $5 \mu \mathrm{l}$ of $2 \mathrm{M} \mathrm{FeCl}_{3}$ were added to the pooled chloroform phase. The absorbance of the purple iron-salicylic acid complex, which developed in the aqueous phase was measured at $527 \mathrm{~nm}$ (Meyer et al., 1992). Production of SA by biocontrol agents was calculated using a standard graph with SA dissolved in succinate medium and the

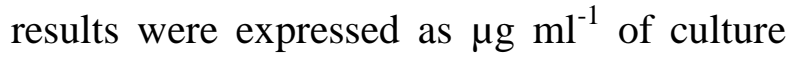
filtrate.

\section{Compatibility between biocontrol agents}

The compatibility of different antagonistic bacteria among themselves was tested by streaking the antagonistic test bacterium vertically on one side and streaking the other bacterium perpendicularly up to the test bacterium. The growth of both the bacteria were observed and recorded as positive or negative. The compatibility between T.viride and bacterial isolates was also tested.

\section{Results and Discussion}

\section{Organic amendments and $F$. oxysporum}

In the present study, the extract of mahua cake was found exhibit higher inhibitory effect on F.oxysporum. Srivastava et al., (1991) reported that the lowest mycelial growth of $F$. solaniwas observed in mahua cake incorporated medium. Pandey et al., (1996) and Mukthar, (2007) The aqueous extract of neem cake inhibited the growth of $F$. o. f. sp. ciceri. Neem cake has been found to completely control $F$. solani infection in 40 day-old soybean plants (Ali, 1997). Bhonde et al., (1999) reported that the extracts of neem cake at 10 per cent were found to be effective against F.solani and caused 80.4 per cent mycelial growth inhibition followed by mahua cake $(75.1 \%)$. Padmodaya and Reddy (1999) noticed that neem cake extract was highly inhibitory to $F$. oxysporum. f. sp. lycopersici. Yelmame et al., (2010) reported that the extract of neem cake showed excellent inhibitory effect against the chilli wilt pathogen $F$. solani. The radial growth of $F$. o. f. sp. psidii was significantly less in neem leaf extract incorporated medium (Srivastava et al., 2011) (Table 1).

\section{Fungicides and $\boldsymbol{F}$. oxysporum}

In the present study, carbendazim, benomyl and Saff at 0.05 per cent completely inhibited the growth of $F$. oxysproum. Guo et al., (1993) obtained best results when carbendazim was used as a basal compound against Fusarium sp. on cotton. Yunusov et al., (1980) used benomyl to manage Fusarium wilt of cotton. Gupta et al., (1997) reported that carbendazim $(100 \mathrm{mg} / \mathrm{ml})$ was highly effective in inhibiting the mycelial growth of F. o. f. sp. Ciceri under in vitro. Christian et al., (2007) observed that the highest inhibition of 28 isolates of pathogenic fungi was obtained with carbendazim, benomyl and captan under in vitro. Carbendazim was observed to reduce the mycelial growth of F.o.f.sp.ciceri to the in vitro while metalaxyl was least effective (Subhani et al., 2011) (Table 2).

\section{Compatibility among biocontrol agents}

Compatibility of Trichoderma spp. with P.fluorescens was assessed by comparing the biocontrol agents applied alone or in combination to suppress take all disease of wheat (Duffy et al., 1996). The present study revealed that there was absence of growth inhibition between the isolates of $P$. fluorescens, B. subtilis and T. viride so that they were compatible among themselves. The interaction between strains of Pseudomonas was studied in vitro and the growth of various combinations of the bacterium in sugar beet spermosphere was found to correlate with their inhibitory behaviours on culture media (Fukui et al., 1994). Thilagavathy (2005) reported that strains of $P$. fluorescens $\left(\mathrm{Pf}_{1}\right.$ and $\mathrm{Pf}_{15}$ ) were compatible in vitro with $B$. subtilis 
$\left(\mathrm{Bs}_{10}\right)$ and T. viride. Latha (2006) observed that $P$. flourescens $\left(\mathrm{Pf}_{1}\right)$ and $B$. subtilis $\left(\mathrm{Bs}_{16}\right)$ were compatible.

\section{Mode of action}

\section{Antibiosis}

In the present investigation, antibiotic of $\mathrm{Pf}_{1}$ exhibited more inhibitory effect on $F$. oxysporum followed by $\mathrm{Pf}_{2}, \mathrm{BS}_{10}$ and $\mathrm{BS}_{2}$. Several strains of Pseudomonas spp. and Bacillus spp. produce wide array of antibiotics which include lacton, 2- 4 diacetylphloroglucinol (2-4 DAPG), HCN, oligomycin, oomycin A, phenazine, pyrolnitrin, pyocyanin, surfactin and several uncharacterized molecules (Kim et al., 1989; Keel and Defago, 1997; Whipps, 1997; Nielson et al., 1998).

Florescent pseudomonads in the plant rhizosphere have been found to improve the plant growth and suppression of plant disease by the production of antibiotics, siderophores, hydrolytic enzymes and HCN (Ahmad and Khan, 2001).John Bainton et al., (2002) reported that the naturally occurring fluorescent pseudomonads produced the antibiotic, 2-4 DAPG. Bacillus spp produced different inhibitory agents which have been categorized in peptide derivative family (Stein, 2005; Tamehiro et al., 2002). Bacilysocin, a novel and broad spectrum phospholipid antibiotic was purified from $B$. subtilis strain 168 (Tamehiro et al., 2002). Srivastava and Salini (2009) reported that $P$. fluorescens produced secondary metabolites such as siderophore, HCN and protease which showed antagonistic activity against Fusarium spp.

\section{Volatiles and disease suppression}

In the present investigation, the inhibitory effect of volatiles released by $\mathrm{Tv}_{1}$ was more pronounced than that of $\mathrm{Pf}_{1}$ and $\mathrm{BS}_{10}$.
Diffusible volatile compounds produced by $T$. viride and $T$. harzianum inhibited the germination and mycelial growth of $F$. oxysporum (Michrina et al., 1995; Pandey et al., 1997).

The volatile metabolite furanone produced by $P$. aureofaciens showed antifungal activity against $F$. solani, $F$. oxysporum, $P$. ultimum and Thielaviopsis bassicola (Paulitz et al., 2000). Paramasivam (2006) reported the involvement of volatile and nonvolatile antibiotic compounds released by Trichoderma spp. against the sugar beet root rot pathogen $S$. rolfsii. Bacterial strains of $P$. fluorescens inhibited the mycelial growth of $F$. o. f. sp. dianthi by production of volatile metabolites under laboratory condition (Karimi et al., 2007). Retarded radial growth of $F$. oxysporum infecting groundnut was due to the volatile and non- volatile metabolites produced by Trichoderma spp. (Rajeswari and Kannabiran, 2011).

The isolate $\mathrm{Bs}_{10}$ was found to release volatiles that was inhibitory to F.oxysporum. Bacillus spp are ubiquitous in the environment (Nicholson, 2004) and found associated with antifungal activity by producing volatile compounds as well as non-volatile substances (Ryder et al., 1999; Bhaskar et al., 2005).

\section{HCN and disease suppression}

Production of $\mathrm{HCN}$ by certain strains of fluorescent pseudomonads has been involved in the suppression of soil-borne pathogens (Voisard et al., 1989). In our study, production of $\mathrm{HCN}$ was very strong in $\mathrm{Pf}_{1}$ than in $\mathrm{Pf}_{2}$. Role of $\mathrm{HCN}$ in disease suppression has been demonstrated by several scientists in various crops (Stutz et al., 1986; Voisard et al., 1989; Defago et al., 1990). $\mathrm{HCN}$ is the common secondary metabolite produced by rhizosphere pseudomonads (Schippers et al., 1990). Meena et al., (2001) compared the HCN production of several 
strains of $P$. fluorescens and their efficacy in controlling root rot of groundnut caused by M. phaseolina. Pseudomonads releasing HCN were reported in the rhizosphere of tobacco in soils suppressive to $T$. bassicola, casual agent of black root rot of tobacco (Ramette et al., 2006).

\section{Siderophores and disease suppression}

Pseudomonads generally produce fluorescent, yellow-green, water soluble siderophres. The siderophores are either pyoveridins or pseudobactins. Production of the siderophres has been linked to the disease suppressive potential of certain florescent pseudomonads. In the present study, the strain $\mathrm{Pf}_{1}$ produced more quantity of siderophore than $\mathrm{Pf}_{2}$ and the siderophore was hydroxymate type. The fungal strain $\mathrm{Tv}_{1}$ also produced siderophore.

Siderophore of Pseudomonas spp inhibited the chlamydospore germination of $F$. $s$. f. sp. lini, F. oxysporum f.sp. cucurbitae and F. o. f. sp. cucumerinum (Sneh et al., 1984; Wong et al., 1984). Klopper et al., (1988) documented the production of fluorescent siderophore by $P$. fluorescens which was attributed to its antagonistic action. Ake et al., (1991) reported that under iron deficiency, the culture filtrate of all strains of Trichoderma contained coprogen, coprogen B and ferricrocin as siderophore. $T$. longi and $T$. pseudokoningii produced fuigen type of siderophore. The hydroxymate type of siderophore was ferribactin produced by $P$. fluorescens (Linget et al., 1992). Lim et al., (1999) showed that the siderophore of $P$. fluorescens GL20 inhibited spore germination and hyphal growth of $F$. solaniin vitro and reduced the disease incidence with enhanced plant growth. Siderophore of $P$. fluorescenswas inhibitory to the growth of $M$. phaseolina in vitro(Meena et al., 2001).B. subtilis (BSCBE4), P. chlororaphis (PA23) and $P$. fluorescens produced both hydroxymate and carboxylate type of siderophores (Mathiyazhagan et al., 2004). Ahmed et al., (2008) reported that siderophore production and antifungal activity was exhibited by 10 to 12.7 per cent of pseudomonas isolates.

Table.1 Effect of oil cake extracts against $F$. oxysporumin vitro

\begin{tabular}{|r|l|c|c|}
\hline S.No. & \multicolumn{1}{|c|}{ Treatments } & $\begin{array}{c}\text { Mycelial } \\
\text { growth(cm) }\end{array}$ & $\begin{array}{c}\text { Per cent reduction } \\
\text { over control }\end{array}$ \\
\hline $\mathbf{2}$ & Castor cake $(10 \%)$ & 6.10 & $\mathbf{3 2 . 2 2}$ \\
\hline $\mathbf{3}$ & Gingelly cake $(10 \%)$ & 4.38 & $\mathbf{5 1 . 3 3}$ \\
\hline $\mathbf{4}$ & Mahua cake $(10 \%)$ & 3.53 & $\mathbf{6 0 . 7 7}$ \\
\hline $\mathbf{5}$ & Coconut cake $(10 \%)$ & 7.48 & $\mathbf{1 6 . 8 8}$ \\
\hline $\mathbf{6}$ & Cotton cake $(10 \%)$ & 7.20 & $\mathbf{2 0 . 0 0}$ \\
\hline $\mathbf{7}$ & Control & 9.00 & - \\
\hline $\mathbf{C D}$ & & $\mathbf{0 . 3 4}$ & \\
\hline
\end{tabular}


Table.2 Efficacy of fungicides against the growth of $F$. oxysporum

\begin{tabular}{|c|c|c|c|c|c|}
\hline \multirow[t]{3}{*}{ Fungicides } & \multirow{2}{*}{\multicolumn{4}{|c|}{$\begin{array}{c}\text { Mycelial growth (cm) / Reduction over control (\%) } \\
7 \text { DAI* } \\
\text { Concentration (ppm) }\end{array}$}} & \multirow[t]{2}{*}{ Mean } \\
\hline & & & & & \\
\hline & 500 & 1000 & 1500 & 2000 & \multirow[b]{2}{*}{0.70} \\
\hline Carbendazim & $\begin{array}{c}0.00 \\
(0.70) \\
100.00\end{array}$ & $\begin{array}{l}0.00 \\
(0.70) \\
100.00\end{array}$ & $\begin{array}{c}0.00 \\
(0.70) \\
100.00\end{array}$ & $\begin{array}{c}0.00 \\
(0.70) \\
100.00\end{array}$ & \\
\hline Copper oxychloride & $\begin{array}{l}5.8 \\
(2.4) \\
35.55\end{array}$ & $\begin{array}{l}3.5 \\
(1.87) \\
61.11\end{array}$ & $\begin{array}{l}1.1 \\
(1.04) \\
87.77\end{array}$ & $\begin{array}{l}1.1 \\
(1.04) \\
87.77\end{array}$ & 1.58 \\
\hline Kocide & $\begin{array}{l}7.2 \\
(2.68) \\
20.00\end{array}$ & $\begin{array}{c}6.0 \\
(2.45) \\
33.33\end{array}$ & $\begin{array}{l}1.8 \\
(1.35) \\
80.00\end{array}$ & $\begin{array}{l}1.8 \\
(1.36) \\
80.00\end{array}$ & 1.96 \\
\hline Benomyl & $\begin{array}{c}0.00 \\
(0.70) \\
100.00\end{array}$ & $\begin{array}{c}0.00 \\
(0.70) \\
100.00\end{array}$ & $\begin{array}{c}0.00 \\
(0.70) \\
100.00\end{array}$ & $\begin{array}{l}0.00 \\
(0.70) \\
100.00\end{array}$ & 0.70 \\
\hline $\begin{array}{l}\text { Saff }(\text { carbendazim } 12 \% \\
\text { + mancozeb } 64 \%\end{array}$ & $\begin{array}{c}0.00 \\
(0.70) \\
100.00\end{array}$ & $\begin{array}{c}0.00 \\
(0.70) \\
100.00\end{array}$ & $\begin{array}{c}0.00 \\
(0.70) \\
100.00\end{array}$ & $\begin{array}{l}0.00 \\
(0.70) \\
100.00\end{array}$ & 0.70 \\
\hline $\begin{array}{l}\text { Curzate (cymoxanil } \\
8 \% \text { + mancozeb } 64 \% \text { ) }\end{array}$ & $\begin{array}{c}8.0 \\
(2.82) \\
11.11\end{array}$ & $\begin{array}{c}8.1 \\
(2.83) \\
10.00\end{array}$ & $\begin{array}{c}4.2 \\
(2.05) \\
53.33\end{array}$ & $\begin{array}{c}4.8 \\
(2.19) \\
46.66\end{array}$ & 2.47 \\
\hline Control & $\begin{array}{c}9.00 \\
(3.00)\end{array}$ & $\begin{array}{c}9.00 \\
(3.00)\end{array}$ & $\begin{array}{c}9.00 \\
(3.00)\end{array}$ & $\begin{array}{c}9.00 \\
(3.00)\end{array}$ & 3.00 \\
\hline Mean & 1.85 & 1.75 & 1.36 & 1.38 & - \\
\hline
\end{tabular}

Figures in parentheses are square root transformed values; *DAI - days after inoculation

\begin{tabular}{|l|l|l|}
\hline $\mathbf{C D}(\mathbf{P}=\mathbf{0 . 0 5})$ & $=$ & 0.39 \\
\hline Fungicide & $=$ & 0.29 \\
\hline Concentration & $=$ & 0.77 \\
\hline Fungicide $\times$ Concentration
\end{tabular}

Table.3 Characterization of B.subtilis

\begin{tabular}{|r|l|c|c|}
\hline S1.No. & Diagnostic tests & $\mathbf{B s}_{\mathbf{1 0}}$ & $\mathbf{B s}_{\mathbf{2}}$ \\
\hline $\mathbf{1 .}$ & Gram reaction & + & + \\
\hline $\mathbf{2 .}$ & KOH test & - & - \\
\hline $\mathbf{3 .}$ & Growth at $45^{\circ} \mathrm{C}$ & + & + \\
\hline $\mathbf{4 .}$ & Growth in $7 \% \mathrm{NaCl}$ & + & + \\
\hline $\mathbf{5}$. & Citrate utilization & + & + \\
\hline $\mathbf{6 .}$ & Anaerobic growth & - & - \\
\hline $\mathbf{7 .}$ & Starch hydrolysis & + & + \\
\hline $\mathbf{8 .}$ & Catalase test & + & + \\
\hline
\end{tabular}


Table.4 Characterization of $P$. fluorescens

\begin{tabular}{|c|l|c|c|}
\hline Sl.No. & \multicolumn{1}{|c|}{ Diagnostic tests } & Pf $_{\mathbf{1}}$ & $\mathbf{P f}_{\mathbf{2}}$ \\
\hline $\mathbf{1 .}$ & Gram reaction & - & - \\
\hline 2. & KOH test & + & + \\
\hline 3. & $\begin{array}{l}\text { Pigment production in King's B } \\
\text { medium }\end{array}$ & + & + \\
\hline 4. & Growth at $4{ }^{\circ} \mathrm{C}$ & + & + \\
\hline $\mathbf{5 .}$ & Growth at $41^{\circ} \mathrm{C}$ & - & - \\
\hline $\mathbf{6 .}$ & Arginine dihydrolase & + & + \\
\hline $\mathbf{7 .}$ & Gelatin liquefaction & + & + \\
\hline 8. & Levan formation & - & - \\
\hline
\end{tabular}

\section{Salicylic acid}

Maurhofer et al., (1994) observed that certain PGPR strains are capable of producing SA and are responsible for the induction of ISR in plants. In the current study, SA production was observed to be more in $\mathrm{Pf}_{1}$ while it was less in $\mathrm{Bs}_{10}$. Role of $\mathrm{SA}$ producing $P$. aeruginosa in disease suppression was studied by Buysens et al., (1996). Inoculation of roots of chickpea with $P$. fluorescens strain $\mathrm{H} 92$ (or) with synthetic 0-acetyl salicylic acid induced systemic resistance against the charcoal rot fungus, $M$. phasiolina (Srivastava et al., 2000).

Meena et al., (2001) reported that production of SA was maximum in $P$. fluorescens strain $\mathrm{Pf}_{1}$ followed by ALR-7 and Pf MDU 2 isolates. There was a significant relationship between inhibitory activity of $P$. fluorescens strains in vitro and their level of SA production. SA production has been observed for several bacterial strains and exogenously applied SA induces resistance in plant species (Bakker et al., 2003).

\section{References}

Ahmad, M. and Khan, M.S. 2001. Assessment of plant growth promoting activities of rhizobacterium Pseudomonas putida under insecticide stress. J. Microbial., 1:54 - 64 .
Ahmed, F., Ahmed, I. and Khan, M. S. 2008. Screening of free living rhizosphere bacteria for their multiple plant growth promoting activities. Microbiol. Res., 168: 173-181.

Anke, H., Kinn, J., Bergquist, K.E. and Stemer, O.1991. Production of siderophores by strains of the genus Trichoderma isolation and characterization of the new lipophilic coprogen derivatives, palmitoglycoprogen. Bio 1. Metabiol., 4: 176-180.

Bakker, A.W. and Schipper, B. 1987. Microbial cyanide production in the rhizosphere in relation to potato yield reduction and Pseudomonas spp. Mediated plant growth stimulation. Soil Boil. Biochem.19:451457.

Bakker, P.A.H.M., Ran, L.X., Pieterse, C.M.J. and VanLoon, L.C.2003. Understanding the involvement of rhizobacteria mediated induction of systemic resistance in biocontrol of plant disease. Can. J. Plant Pathol., 25: 5-9.

Bhaskar, C., Anitha, P., Lok Man, S.P., Pankaj, T., Bhavesh, K. and Niharika, C., 2005. Diffusible and volatile compounds produced by an antagonistic Bacillus subtilis Strain cause structural deformations in pathogenic fungi in vitro. Microbiol Res.,, 160: 75-81.

Bonde, S.B., Deshpande, S.G. andSharma, R.N. 1999. In vitro evaluation on Inhibitory nature of some neem formulation against plant pathogenic fungi. Hindustan Antibiotic Bulletin, 41(4): 22-24.

Christian, L., Morel, N. and Luiz, R. 2007. In 
vitro susceptibility to fungicides by Invertebrate-pathogenic and saprobic fungi. Mycopatholgia, 164 (9): 39-47.

Corell, J.2005. Fusarium wilt symptoms In: Reproduced from the Crop Protection Compendium (Eds). CAB international Wallingford, UK.

Dennis, C. and Webster, J. 1971. Antagonist properties of species group of Trichoderma I. Production of non-volatile antibiotics. Trans. Br. Mycol. Soc., 57: 25-39.

Dileep, C., Dileep kumar, B.S. and Dube, H.C. 1998. Influence of amino acid, organic acid and sugar on growth, fluorescence and siderphore production of fluorescent psuedomonads. Indian J. Exp. Biol., 36: $429-431$.

Dubey, S.C. and Patel, B. 2000. In vitro evaluation of some oil cakes and plant extracts against Thanetophorus cucumeris, Gliocladium virens and Trichoderma viride. J. Mycol. Pl. Pathol., 30(3): 411-413.

Duffy, B.K., Simon, A. and Weller, D.M. 1996. Combination of Tricoderma koningii with fluorescent psuedomonads for control of take - all on wheat. Phytopathology, 86: 188-194.

Fukui, R., Schorth, M.N., Hendson, M. and Hancock, J.G. 1994. Interaction between strains of psuedomonads in sugar beet sphermospheres and the relationship to pericarp colonization by Pythium ultimum in siol. Phytopathology, 84:1322-1330.

Goulart, A.C.P. 1992. Effect of fungicides on the control of pathogens on cotton (Gossypium hirsutum) seeds. Summa phytopathologic, 18: 173-177.

Gupta, S.K., Upadhyay, J.P. and Ojha, K.H. 1997. Effect of fungicidal seed treatment on the incidence of chickpea wilt complex. Ann. Pl. Prot. Sci., 5: 184-187.

Joffe, A. Z., 1973. Fusarium species on groundnut kernals and in groundnut soils Plant Soil 38: 439-446.

John Bainton, N., Michael Lynch, J., Naseby, D. and Alexander Way, J. 2002. Survival and ecological fitness of Pseudomonas fluorescence genetically engineered with Dual biocontrol mechanisms. Can. J. Microbiol., 56(2): 706-709.

Karimi, E., Rouhanil, H., Zafarilm, D.,
Khodakaramian, G.H. and Taghinasab, M. 2007. Biological control of Vascular Wilt disease on carnation caused by Fusarium oxysporum f. sp. dianthi by Bascillus and Pseudomonas strains isolated from Rhizocsphere of carnation. J. Sci. and Technol. Agric. \& Natur. Resour., 11(41): Fall Isf. Univ. Technol., Isf., Iran.

Keel, C. and Defago, G. 1997.Interactions between beneficial soil bacteria and root pathogens: mechanisms and ecological impact. In: Gange, A.C., Brown V.K. (Eds.). Multitrophic interactions in terrestrial system. Oxford: Blackwell Science, p. 27-47.

Kim, D.H., Martyn, R.D. and Magil, C.W. 1993. Mitochondrial DNA-relatedness Among formae specialis of Fusarium oxysporum in the cucurbitaceae. Phytopathology. 83: 9197.

Kim, B. S.,Moon, S. S. and Hwang, B.K. 1999. Isolation, identification and antifungal activity of macrolide antibiotic, oligomycin A, produced by Streptomyces libani. Can. J. Bot. 77:850-858.

Kloepper, J. W., Schroth, M. N. and Miller, T. D. 1980. Effects of rhizosphere Benefit plant protection. In: ISI Atlas of Science, Institute for Scientific information, Philadelphia, p 60-64.

Laha, G. S. , Verma, J. P. and Singh, R. P. 1996. Effectiveness of fluorescent Pseudomonads in the management of sclerotial wilt of cotton. Indian Phytopath., 49:3-8.

Lam, S. K. and Ng, T.B. 2001. First simultaneous isolation of a ribosome inactivating protein and an antifungal protein from a mushroom (Lyophyllum shimeji) together with evidence for synergism of their antifungul effects. Archi. Biochem. Biophysics., 392 (2): 271-280.

Latha, P.2006. Eco-friendly management of early blight in tomato (Lycopersicon esculentum Mill.) caused by Alternaria solani (Ellis and Martin) Jones and Grout, M.Sc., (Agri.) Thesis, Tamil Nadu Agricultural University, Coimbatore, India. 185pp.

Lim, H.S., Lee, J.M., Kim, S. and Dal, H.S. 1999. Role of siderophore in biological control of Fusarium solani by Pseudomonas fluorescence GL20. Bulletin of the Institute 
for Comprehensive Agricultural Sciences, Kinki-University 7:47-58.

Linget, C., Stylianou, D.G., Dell, A., Wolff, R. Piemont, E. and Abdallah, M. 1992. Bacterial siderophores: the structure of a desferribactin produced by $P$. fluorescens. Tetrahedron Lett., 33:3851-3854.

Mathiyazhagan, S., Kavitha, K., Nakkeeran, S., Chandrasekar, G., Manian, K., Renukadevi, P., Krishnamoorthy, A.S. and Fernado, W.G.D. 2004. PGPR Mediated managemaent of stem blight of Phyllanthus amarus (Schum and Thonn) caused by Corynespora cassiicola Berk and Curt) Wel. Arch. Phytopathol. Plant. Protect., 37: 183-199.

Maurhofer, M., Hase, C., Maurwly, D., Metraux, J.P. and Defago, G. 1994. Induction of systemic resistance of tobacco to tobacco necrosis virus by the root colonizing Pseudomonas fluorescens strain CHAO: influence of the gac A gene and of pyoverdine production. Phytopathol., 84: 136-146.

Meyer, J. M., Azelvander, P. and Georges, C.1992. Iron metabolism in Pseudomonas: Salicyclic acid, a siderophoree of Pseudomonas fluorescenes CHAO. Biofactoors., 4:23-27.

Michrina, J., Michalikova, A., Rohacik, T. and Kulichova, R. 1995. Antibiosis as a Possible mechanism of antagonistic action of Trichoderma harzianum against Fusarium culmorum, Ochrana Rostlin, 31: 177-184.

Mukhtar, I. 2007. Comparison of Phytochemical and chemical control of Fusarium oxysporum f. sp. ciceri. Mycopath., 5 (2): $107-110$.

Nicholson, R.L. and Hammerschmidt, R. 1992. Phenolic compound and their role in Disease resistance. Ann. Rev. Phytopathol., 30: 369-389.

Pandey, K.K and Uapadhyay, J.P. 1997. Selection of potential biocontrol agents based On production of volatile and non volatile antibiotics. Veg. Sci. 24 (2): 140 -143.

Pandey, K.K and Uapadhyay, J.P. 1997. Selection of potential biocontrol agents based On production of volatile and non-volatile antibiotics. Veg. Sci. 24 (2): 140 -143.
Paramasivam, M. 2006. Management of tropical sugarbeet root rot (Sclerotium rolfsii Sacc.) through ecofriendly methods. Ph.D., (Ag.) Thesis, Agricultural College And Research Institute, Tamil Nadu Agricultural University, Coimbatore.

Prakasam, V., Valluvaparidasan, V. and Jeyarajan, R. 1993. A handbook of field crop disease. A.E. Publication, Coimbatore, 114pp.

Rajeswari, P. and Kannabiran, B. 2011. In vitro effects of antagonistic microorganisms on Fusarium oxysporum (Schlecht. Emend. Synd \& Hans) infecting Arachis hypogaea L. J. Phytol., 3(3): 83-85.

Ramette, A.,. Loy, M. and Defago, G. 2006. Genetic diversity and biocontrol protection Of fluorescent psuedomonads producing phloroglucinols and hydrogen cyanide from Swiss soils naturally suppressive or conducive to Thieviopsis basicola mediated black rot of tobacco. FEMS Microbial Ecol., 55(3): 369-381.

Ramteke, P. K. and Kamble, S. S. 2011. Physiological studies in Fusarium solani causing rhizhome rot of ginger (Zingiber officinale Rosc.). The Bioscan 6(2):195197.

Rasheed, S., Dawar, S. and Ghaffar, A. 2004. Location of fungi in Groundnut seed. Pak.j. Bot., 36(3): 663-668.

Reeves, M., Pine, L. Neilands, J.B. and Bullows, A. 1983. Absence of siderophore Activity in Legionella sp. grown in iron deficient media. J. Bacteriol., 154: 324-329.

Rosales, A. M., Thomashow, L., Cook, R.J. and Mew, T.W. 1995 Isolation and Identification of antifungul metabolites produced by rice associated antagonistic Pseudomonas sp. Phytopathol., 85: 10281032.

Ryder, M.H., Yan,Z., Terrace, T.E., Rovira, A.D., Tang, $W$ and Correll,R.L. 1999.Use of strains of Bacillus isolated in China to suppress take-all and Rhizoctonia root rot and promote seedling growth of glasshouse grown wheat in Australian soils. Soil Biology and Biochemistry, 31:19-29.

Sadasivam, S. and Manickam, A. 1992. Biochemical Methods for Agricultural Sciences, Wiley Eastern Ltd, New Delhi, p 
246.

Schaad, N. W. 1992. Laboratory Guide for Identification of Plant Pathogenic Bacteria. APS Press, St. Paul, Minnesota, 164 pp.

Schippers, B. 1988. Biological control of pathogens with rhizobacteria. Trans British Soc. Land. B. Biol. Sci., 318: 283-293.

Schmitz, H. 1930. Poisoned food technique. In: Industrual and Engineering Chemical Analyst,. p. 361-365.

Schwyn, B. and Neilands, J.B. 1987. Universal chemical assay for the detection and Determination of siderophore. Anal. Biochem., 169: 47-56.

Shaik, M. H. 1974. Studies on wilt of gram (Cicer arieinum L.) caused by Fusarium Oxysporum f.sp. cicieri in Marathwada Region. M. Sc. (Agri.). Thesis, Marathwada Krishi Vidyapeeth, Parbhani, India.

Sneh, B., Dupler, M., Elad, Y. and Baker,R. 1984. Chlamydospore germination of Fusarium oxysporum f.sp. cucumerinum as affected by fluorescent and lytic bacteria from Fusarium suppressive soil. Phytopathology, 74: 1115-1124.

Snow, G. A. 1984. Mycobacin. A growth factor for Macrophomina joheni II Degradation and identification of Fragments. J. Chem. Soc., 25: 2588-2596.

Stein, T. 2005. Bacillus subtilis antibiotics: structures, syntheses and specific functions. Mol. Microbiol., 56: 845-857.

Stutz, E.W., Defago, G. and Kern,H. 1986. Naturally occurring fluorescent Psuedomonads involved in suppression of black root rot of tobacco. Phytopathology, 76: 181-185.
Subhani, M.N., Sahi, S.T., Hussain, S., Ali, A., Iqbal, J. andHameed, K. 2011. Evaluation of various fungicides for the control of gram wilt caused by Fusarium oxysporum f.sp. ciceri. Afr. J. Agrl. Res., 6(19): 45554559.

Tamehiro, N., Okamoto- Hosoya, Y., Okamoto, S., Ubukata, M. Masa Hamada, M., Naganawa, H. and Ochi, K. 2002. Bacilysocin, a novel phospholipid antibiotic produced by Bacillus subtilis 168 . Antimicrob. Agents Chemother., 46: 315320.

Thilagavathi, R., Saravanakumar, D., Ragupathi, N. and Samiyappan,R. 2007. Acombination of biocontrol gents improves the management of dry root rot (Macrophomina phaseolina) in green gram. Phytopathol. Mediterr., 46: 157-167.

Vogeli, V., Mein, J.E. and Boller, T. 1998. Coordinated regulation of chitinase and $\mathrm{B}-1,3$ glucanase in bean leaves, Planta, 174: 364372. www. Indiastat. com, 2011.

Voisard, C., Keel, C., Haas, D. and Defago, G. 1989. Cyanide production by Pseudomonas fluorescens helps suppress black root rot of tobacco under gntobiotic conditions. EMBO J., 8: 351-358.

Wang, H., Chang, K. F., Kwang, S. F., Turnball, G.D., Howard, R.J., Blade, S.F., and Callan, N.W. 1999. Fusarium root rot of coneflower seedlings and integrated control using Trichoderma and fungicides. Bio. Control. 50: 317-329.

Whipps, J. M. 2001. Microbial interactions and biocontrol in the rhizosphere, J. Exponential Bot., 52: 487-511.

\section{How to cite this article:}

Vasumathi, S. and Ahila Devi, P. 2020. Integrated Approach for the Management of Soil Borne Disease Fusarium oxysporum in vitro in Groundnut. Int.J.Curr.Microbiol.App.Sci. 9(06): 30323044. doi: https://doi.org/10.20546/ijcmas.2020.906.365 